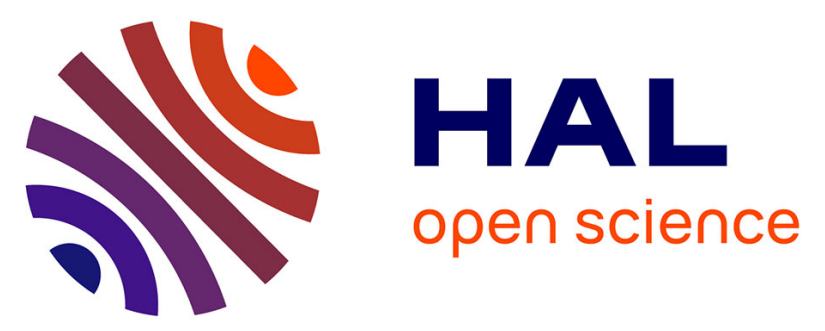

\title{
Detrital rutile tracks the first appearance of subduction zone low $T / P$ paired metamorphism in the Palaeoproterozoic
}

Inês Pereira, Craig D Storey, James R Darling, Hugo Moreira, Robin A Strachan, Peter A Cawood

\section{To cite this version:}

Inês Pereira, Craig D Storey, James R Darling, Hugo Moreira, Robin A Strachan, et al.. Detrital rutile tracks the first appearance of subduction zone low $\mathrm{T} / \mathrm{P}$ paired metamorphism in the Palaeoproterozoic. Earth and Planetary Science Letters, 2021, 570, pp.117069. 10.1016/j.epsl.2021.117069 . hal-03284048

\section{HAL Id: hal-03284048 \\ https://hal.science/hal-03284048}

Submitted on 12 Jul 2021

HAL is a multi-disciplinary open access archive for the deposit and dissemination of scientific research documents, whether they are published or not. The documents may come from teaching and research institutions in France or abroad, or from public or private research centers.
L'archive ouverte pluridisciplinaire HAL, est destinée au dépôt et à la diffusion de documents scientifiques de niveau recherche, publiés ou non, émanant des établissements d'enseignement et de recherche français ou étrangers, des laboratoires publics ou privés. 


\section{Detrital rutile tracks the first appearance of subduction zone low}

\section{T/P paired metamorphism in the Palaeoproterozoic}

\section{Inês Pereira ${ }^{1,2^{*}}$, Craig D. Storey², James R. Darling ${ }^{2}$, Hugo Moreira ${ }^{2,3}$, Robin A.}

\section{Strachan², Peter A. Cawood ${ }^{4}$}

${ }^{1}$ Université Clermont Auvergne, CNRS, IRD, OPGC, Laboratoire Magmas et

6 Volcans, F-63000 Clermont-Ferrand, France, ines.pereira@uca.fr

$7{ }^{2}$ School of the Environment, Geography and Geosciences, University of Portsmouth,

8 Portsmouth, PO1 3QL, Hampshire, United Kingdom, craig.storey@port.ac.uk;

9 james.darling@port.ac.uk; rob.strachan@port.ac.uk

${ }^{3}$ Géosciences Montpellier CNRS, Université de Montpellier, 34090 Montpellier,

11 France, hugo.moreira@umontpellier.fr

${ }^{4}$ School of Earth, Atmosphere and Environment, Monash University, Wellington Rd, Clayton VIC 3800, Australia, peter.cawood@monash.edu

\section{ABSTRACT}

Earth is unique in the Solar System as the only planet characterised by an active plate tectonic regime. However, there is still no consensus on whether this was fully operational in the Archaean or if it did not develop until the Proterozoic. The metamorphic record offers valuable insight into this debate, since paired, high and low T/P metamorphic conditions are a hallmark of modern plate tectonics. However, much of the metamorphic rock record has either been eroded or overprinted by subsequent tectonothermal events. To address this issue, we examine the detrital rock record and evaluate the potential of rutile, a mineral that forms during subduction and deep-crustal metamorphic processes, as a proxy to track the existence of low T/P and paired metamorphism. At temperatures of $550^{\circ} \mathrm{C}$, rutile is mostly stable at pressures higher than ca. 13 kbar. We use this relationship and the $\mathrm{Zr}$-in-rutile thermometer to determine peak metamorphic temperatures of detrital rutile grains to track 
27 the temporal distribution of low T/P metamorphism. We have compiled a dataset of detrital

28 metamorphic rutile from Archaean to Permian age to trace the occurrence of low and high

29 T/P metamorphism through time. The earliest evidence of low T/P from detrital rutile is at

30 about 2.1 Ga. This agrees with the earliest evidence of eclogite facies conditions from the

31 rock record and it also implies that these conditions must have been more prevalent than the

32 present rock record seems to indicate. Together, our study confirms that subduction zone

33 low T/P metamorphism has been fully operating since at least the late Palaeoproterozoic.

34 Keywords: metamorphic proxy; low T/P metamorphism; paired metamorphism; detrital rutile;

35 plate tectonics; Palaeoproterozoic

36

37

\section{INTRODUCTION}

The cyclic formation of supercontinents by modern plate tectonics is of critical importance to the secular evolution of the Earth System. It impacts, for example, the oxygenation of the atmosphere (Campbell and Squire, 2010), nutrient addition to the oceans (Reinhard et al., 2017; Zerkle, 2018), and the geological record itself (Dhuime et al., 2017; Li et al., 2003). Earth experienced major changes between 3 and 2 Ga (Cawood et al., 2018; Condie, 2018; Brown et al., 2020), including variations in the composition of the continental crust (Laurent et al., 2014a), and a change in the rate of continental growth (Dhuime et al., 2012). Several of these changes have been linked to the onset of subduction as a response to the secular cooling of the mantle. However, subduction may have been localized and unstable on the early Earth and therefore may not in itself provide evidence for modern plate tectonics, which requires sustained subduction (Brown et al., 2020; Cawood et al., 2018). It is therefore necessary to investigate the geological record for evidence of the major hallmarks of modern plate tectonics, namely the existence of self-sustained, interlinked subduction systems (Lenardic, 2018).

The metamorphic rock record provides strong evidence for sustained subduction for at least the last 700 million years (Brown et al., 2020; Brown and Johnson, 2018; Stern, 
2005) with the prevalence of low-temperature eclogite and blueschist facies, and paired

54 metamorphism. This record of cold-subduction is widespread in the Phanerozoic (Brown and Johnson, 2018), but the apparent absence of evidence for low geothermal gradients $(T / P)$ in the greater part of the Proterozoic and during the Archaean (Brown et al., 2020; Brown and Johnson, 2018) has been argued as indicating that a different tectonic regime prevailed prior to the Neoproterozoic (Kusky, 2020; Stern, 2005). Exceptionally, late Palaeoproterozoic, partially retrogressed eclogite units have been reported (e.g. François et al., 2018; Ganne et al., 2012; Melnik et al., 2021; Weller and St-Onge, 2017), providing a growing body of evidence for cold-subduction and strong plates that allowed the exhumation of these units. However, due to the rather fragmentary and scarce repository of rocks recording these conditions, the assertion that modern plate tectonics has been fully operating since then has proven contentious. The period between the Palaeoproterozoic and the early Neoproterozoic may be characterized by an intermediate plate tectonic cycle between early Earth and modern-like endmembers (Brown and Johnson, 2018).

The identification of certain metamorphic conditions relies on the preservation of indicator minerals; for example, the presence of lawsonite or glaucophane is indicative of HP conditions. However, these hydrous mineral phases are prone to dehydration reactions during retrogression from HP conditions (Skelton et al., 2019; Tsujimori et al., 2006) and therefore pristine blueschist and low-T eclogite are rare even in the modern rock record (Lombardo and Rolfo, 2000; Whitney and Davis, 2006). In this study, we aim to provide a new way of probing the metamorphic record and assessing preservation bias, particularly of low $T / P$ metamorphism, by using detrital rutile.

Rutile most commonly occurs after Ti-bearing precursors in intermediate to high pressure metamorphic rocks, particularly the latter (Angiboust and Harlov, 2017; Liou et al., 1998; Zack and Kooijman, 2017). It is also found within upper amphibolite and granulite facies terrains, and associated with either magmatic or lower temperature and pressure 
Kotková and Harley, 2010). More rarely, rutile has been described as replacing ilmenite at

81 intermediate grades $\left(480-550^{\circ} \mathrm{C}\right)$ in metapelites (Luvizotto et al., 2009). Alongside its higher

82 stability at high pressures, Zr concentrations in rutile are temperature-dependent (Kohn,

83 2020; Tomkins et al., 2007; Zack et al., 2004a). Together, this makes rutile an ideal candidate to be used as a proxy of low T/P metamorphism. Although rutile can re-equilibrate during retrogression from higher metamorphic conditions, it is more robust than other minerals such as lawsonite and glaucophane that due to their hydrated nature are prone to re-equilibrate more readily. Rutile is also ubiquitous in detrital rocks, and thus it commonly survives weathering and transport. By investigating the sedimentary archive using detrital rutile we expect to be able to develop a more complete picture of the metamorphic record through time, compared with that derived from currently exposed metamorphic terrains (Brown and Johnson, 2019). This approach will allow: 1) tackling the individual metamorphic evolution of Precambrian terranes whose current crustal exposure is from deeper orogenic roots and thus bias the known metamorphic record towards higher-grade conditions, and 2) investigating Earth's long term metamorphic secular evolution, and its tectonic drivers, at a global scale.

\section{SAMPLES, APPROACH AND METHODS}

We have investigated published Zr-in-rutile geothermometry data from metamorphic rocks (appendix 1) to evaluate the potential of rutile as a proxy for low T/P metamorphism and some of the limitations associated with this approach. We also looked at detrital rutile datasets reporting $\mathrm{U}-\mathrm{Pb}$ ages and a complete range of trace element data that are required for source discrimination and geothermometry, that include $\mathrm{Cr}, \mathrm{Zr}, \mathrm{Nb}, \mathrm{Sn}, \mathrm{Hf}, \mathrm{Ta}$ and $\mathrm{W}$. This results in the first combined data compilation of detrital rutile, using data from six published datasets (Agangi et al., 2020; Flowerdew et al., 2019; Rösel et al., 2018, 2014;

104 Şengün et al., 2020; Zhou et al., 2020), from different regions and depositional ages, 105 culminating in a dataset of detrital rutile ages ranging from the Permian to the Archean 106 (appendix 2). To complement this dataset, we collected new trace element data from $161 \mathrm{U}$ - 
$107 \mathrm{~Pb}$ concordant detrital rutile grains, from samples collected in NW Scotland. These

108 correspond to a stratigraphic succession of Neoproterozoic to Cambrian in age: the Torridon

109 Group and the Ardvreck Group, Eriboll Formation. Six samples were prepared from these

110 units ( 3 from the Torridon Grp. and 3 from the Eriboll Fm.) and rutile grains were handpicked

111 after common mineral separation procedures (see Pereira et al., 2019). Sample locations

112 and U-Pb data for these rutile grains are presented and discussed in Pereira et al. (2020). U-

$113 \mathrm{~Pb}$ concordant rutile grains were then subjected to trace element analysis using LA-ICPMS.

114 BSE images were used to target the same domains as sampled during the $\mathrm{U}-\mathrm{Pb}$ isotopic

115 analysis. Rutile grains included in this study are mostly homogeneous, with no apparent

$116 \mathrm{BSE}$ (trace element composition) zonation, and yield $\mathrm{U}-\mathrm{Pb}$ ages ranging from 1.0 to $2.9 \mathrm{Ga}$.

117 The total dataset comprises 840 analyses (appendix 4).

118 Trace element microanalysis by Laser ablation coupled inductively plasma Mass

119 Spectrometry (LA-ICPMS)

120 Trace elements in rutile were determined using an ASI RESOlution 193nm ArF excimer

121 laser coupled to the ANALYTIK JENA Plasma Quant Elite quadrupole ICP-MS at the

122 University of Portsmouth (UoP). Rutiles were ablated with laser beam diameters between 25

123 and $40 \mu \mathrm{m}$, using an energy density of $\approx 4.0 \mathrm{~J} / \mathrm{cm}^{2}$ and a repetition rate of $5 \mathrm{~Hz}$. Analyses

124 consisted of $20 \mathrm{~s}$ background, $30 \mathrm{~s}$ ablation and sample acquisition, and $5 \mathrm{~s}$ of washout,

125 resulting in $55 \mathrm{~s}$ per analysis. Instrumental parameters and ablation conditions are

126 summarized in the supplementary file A. The following isotopes were analysed: ${ }^{49} \mathrm{Ti},{ }^{29} \mathrm{Si}$,

$127{ }^{25} \mathrm{Mg},{ }^{45} \mathrm{Sc},{ }^{51} \mathrm{~V},{ }^{52} \mathrm{Cr},{ }^{87} \mathrm{Sr},{ }^{89} \mathrm{Y},{ }^{90} \mathrm{Zr},{ }^{93} \mathrm{Nb},{ }^{95} \mathrm{Mo},{ }^{118} \mathrm{Sn},{ }^{121} \mathrm{Sb},{ }^{139} \mathrm{La},{ }^{140} \mathrm{Ce},{ }^{141} \mathrm{Pr},{ }^{146} \mathrm{Nd},{ }^{147} \mathrm{Sm}$,

$128{ }^{153} \mathrm{Eu},{ }^{157} \mathrm{Gd},{ }^{159} \mathrm{~Tb},{ }^{165} \mathrm{Ho},{ }^{166} \mathrm{Er},{ }^{169} \mathrm{Tm},{ }^{172} \mathrm{Yb},{ }^{175} \mathrm{Lu},{ }^{177} \mathrm{Hf},{ }^{181} \mathrm{Ta},{ }^{182} \mathrm{~W},{ }^{208} \mathrm{~Pb},{ }^{232} \mathrm{Th}$ and ${ }^{238} \mathrm{U}$.

129 A sample-standard bracketing method was used to correct for instrumental drift using

130 BCR-2 as the reference material (using reported concentrations from Jochum et al. (2005)).

131 R10 (GEOREM database), BHVO (using reported concentrations from Jochum et al. (2005))

132 and NIST610 and 612 (reported concentrations from Jochum et al. (2011)) were used as 
secondary standards, analysed between unknowns and primary standards in the sample-

134 standard bracketing method. NIST610 and R10 were analysed using a $40 \mu \mathrm{m}$ laser beam

135 diameter. In contrast, for the BHVO reference material, a laser beam of $80 \mu \mathrm{m}$ diameter was

136 used to directly access the attenuation mode of the ANALYTIK JENA ICP-MS, important for

137 stable measurement of ${ }^{49} \mathrm{Ti} \cdot \mathrm{TiO}_{2}$ was used as an internal standard to normalise the intensity

138 of all unknowns, using reference reported values for glasses, and using Ti of $58.8 \mathrm{wt} \%$ for all

139 rutile grains). Data were processed using the software package IOLITE 3.31. For Zr, we

140 obtained $5 \%$ accuracy relative to published values for all glass standards, within $5 \%$ from

141 published values for R10 (GEOREM database) and a $0.06 \mathrm{ppm}$ detection limit. The full

142 instrumental and analytical setup and standard data can be found in appendix 3.

\section{3. ZR-IN-RUTILE GEOTHERMOMETRY APPLIED TO DETRITAL GRAINS}

144 3.1 Application of the Zr-in-rutile thermometer

145 The Zr-in-rutile thermometer has been calibrated based on natural samples by Zack et al.

146 (2004). Several other researchers have subsequently refined the calibration, including

147 Tomkins et al. (2007) who demonstrated a minor pressure dependency, more significant in

148 the alpha-quartz field. These calibrations have been recently revisited by Kohn (2020) who

149 used new natural data, refined previous natural datasets, and combined them with published

150 experimental data into a new equation that we use in this study. In Figure 1, a comparison

151 between temperature estimates obtained by Zr-in-rutile and mineral equilibria using

152 conventional thermobarometry from 14 published studies (appendix 1 ) is presented. In most

153 circumstances, thermobarometry based on element exchange between mineral pairs yields

154 a larger uncertainty than single grain thermometers (Fig. 1). Uncertainties in applying this

155 calibration are around $10-15^{\circ} \mathrm{C}$, which is often the variation achieved taking into account the

156 uncertainty in the assumed pressure (Fig. 1). On the other side, the standard deviation of $\mathrm{Zr}$

157 concentrations between grains within the same sample propagates into a larger uncertainty

158 that often exceeds that obtained from mineral equilibria (Fig. 1). 
The linear correlation between both methods is consistent, yielding a ratio not far

160 from 1 (Fig. 1A). This correlation is improved if the temperature estimate used for the

161 correlation taken from mineral equilibria is adjusted to its uncertainty $\left(R^{2}=0.72\right.$; Fig $\left.1 B\right)$. For

162 instance, often peak conditions are given as a range, and the true value is enclosed in the

163 interval. Instead of the average, we compare the T estimate determined from Zr-in-rutile and

164 check whether the temperature is enclosed by the interval. If so, the value is taken as the true average $\mathrm{T}$ for the correlation. Where this difference is larger than the interval, the uncertainty from the average T estimate from mineral equilibria is either summed or subtracted to obtain the best correlation scenario. In doing so, it becomes clear that for most samples, average $\mathrm{Zr}$ concentrations and their uncertainties have a robust fit with the thermobarometric estimate of their rocks, with a tendency line that is essentially 1:1 (Fig.1).

Regardless of the calibration equation, rutile has to be in equilibrium with zircon and quartz, so that $\mathrm{t}-\mathrm{ZrO}_{2}$ and $\alpha$-quartz activities are 1. As Triebold et al. $(2012,2007)$ demonstrate, by applying a discrimination diagram based on $\mathrm{Cr}$ and $\mathrm{Nb}$ (Meinhold et al., 2008; Zack et al., 2004b), rutile grains that have metafelsic affinity can be presumed to have

174 formed in such conditions. Therefore, a filter was applied to enable distinction between probable protolith sources, and thus to infer silica activity in the system. By applying the $\log (\mathrm{Cr} / \mathrm{Nb})$ following Meinhold et al. (2008), grains with $\log (\mathrm{Cr} / \mathrm{Nb})<0$ and $\mathrm{Nb}>800 \mathrm{ppm}$ were considered as metafelsic and thus yield $a_{\alpha-q u a r t z}=1$, whereas grains with $\log (\mathrm{Cr} / \mathrm{Nb})>0$ or $\mathrm{Nb}<800 \mathrm{ppm}$ were considered metamafic and the $\alpha$-quartz activity is unknown. While at amphibolite facies conditions this discrimination can sometimes fail (metamafic being classified as metafelsic), we stress that metamafic rocks can have $a_{\alpha-\text { quartz }}=1$. Felsic rocks commonly yield zircon and therefore we assume that grains classified as metafelsic-derived yield $a_{t-z r o 2}=1$. Therefore, by applying this filter, we have a high level of confidence in the Zr-in-rutile thermometry outputs. The statistically comprehensive dataset compiled from the literature (supplementary file B) shows that only about $10 \%$ of the cases ( $n$ total $=764$ ) are false positives (i.e. a metamafic-derived grain being discriminated as metafelsic), and rarely 
186 a felsic protolith is discriminated as mafic. It is important to note that from the dataset used

187 to estimate this uncertainty, regardless of protolith composition, quartz was always present $188\left(a_{\alpha-q u a r t z}=1\right)$.

\section{2 $\mathrm{Zr}$ concentration scatter and its significance}

$\mathrm{Zr}$-in-rutile has become a popular tool to retrieve peak temperatures from metamorphic rocks. Several issues have been systematically found from applying this thermometer (CruzUribe et al., 2018; Kooijman et al., 2012; Pape et al., 2016), such as high Zr concentration deviations in grains from the high temperature domain $\left(>800^{\circ} \mathrm{C}\right.$; Fig. 2). Natural scatter present in most metamorphic rocks, and from the subset we have used (appendix 1), is not commonly observed in eclogite (Fig. 2) or blueschist-facies rocks (Gao et al., 2014; Hart et al., 2016), and when present, it is usually envisaged as recording multiple stages during prograde growth (Spear et al., 2006). This imparts some uncertainty when applying this tool to detrital rutile, as one single estimate can represent either the prograde history or natural scatter by other competing processes (e.g., diffusion, local equilibrium, recrystallisation).

While scattering of $\mathrm{Zr}$ concentration in rutile is commonly present in rocks at higher metamorphic grade, the scatter is significantly more limited at a lower grade, regardless of

202 protolith composition (Fig. 2). The significant data scatter in high grade rocks (granulite, migmatite) amounts to commonly less than or around $100^{\circ} \mathrm{C}$ (including rutile as inclusions in other minerals and matrices), but at lower temperatures it implies an overall standard deviation of $\pm 50-60^{\circ} \mathrm{C}$ or even less. Importantly, minimum values/outliers of the highergrade rutile grains are never lower than $600^{\circ} \mathrm{C}$ (Fig. 2), suggesting that re-equilibration does not seem to take place below those temperatures. 
211 eclogite, amphibolite vs eclogite, high-T eclogite vs granulite). However, a few important

212 assumptions (e.g., constraints on rutile phase stability, $\mathrm{Zr}$ diffusion behaviour), support the

213 identification of rutile grains equilibrated at low T/P (Fig. 3). Because at lower temperatures,

214 rutile is not commonly stable at lower than 10 to 12 kbar (Fig. 3; for all types of rock

215 compositions), this implies that all rutile yielding temperatures lower than $550{ }^{\circ} \mathrm{C}$

216 (intersection of minimum low T/P with the rutile-out boundary; yellow star in Fig. 3) will be a

217 proxy for blueschist facies conditions (and low T/P in general).

One of the challenges of utilising $\mathrm{Zr}$ concentrations to retrieve peak-T also resides in

219 the thermal histories of the source terranes. Because trace element contents can reset

220 under certain conditions, the potential impact of $\mathrm{Zr}$ diffusion during cooling or overprinting

221 during a more recent high temperature event (brown dashed lines, Fig. 3) has been

222 considered in agreement with similar reviews from the literature (e.g., Kohn 2020; Tomkins et al., 2007). For a wide range of cooling rates $\left(0.6\right.$ to $\left.75^{\circ} \mathrm{C} / \mathrm{Ma}\right)$, rutile (ca. $\left.200 \mu \mathrm{m}\right)$ grains can start to re-equilibrate at mid- to upper-amphibolite facies during retrogression (Fig. 3). If the source terranes endured polymetamorphism, it would require about $50 \mathrm{Ma}$ at midamphibolite/eclogite facies conditions to re-equilibrate the $\mathrm{Zr}$ in rutile, or less than $1 \mathrm{Ma}$ at granulite facies conditions (Fig. 3). Zirconium re-equilibration at lower temperatures would require unrealistic cooling rates or thermal-overprinting durations, which again reinforces the suitability of the $550^{\circ} \mathrm{C}$ filter as: a) a conservative approach that will only include low-T, low T/P rutile grains, and b) correspond to a real peak-T estimate under low $\mathrm{dT} / \mathrm{dP}$ conditions, that has not been affected by either diffusion or recrystallisation processes under any realistic geological conditions.

As introduced earlier, only in rare circumstances rutile will form at lower than 10-13

234 kbar for $\mathrm{T}<550^{\circ} \mathrm{C}$ (e.g. Luvizotto et al., 2009). Most frequently these are associated with more uncommon protoliths (MgO-rich or CaO-rich metapelites), to fluid-precipitates, and texturally prone not to survive well weathering (due to small size and aggregate-like texture; 
237 Luvizotto et al., 2009). Therefore, any bias resulting from this filter (P of $13 \mathrm{kbar} \&<100 \mathrm{ppm}$

$238 \mathrm{Zr}=550^{\circ} \mathrm{C}$ ) strongly resides when pressures were higher and not lower than our

239 assumption for rutile stability. This implies that we exclude potential low T/P rutile grains

240 derived from higher temperature eclogite facies rocks. Also, this results in a mix in the field

241 of "blueschist" between low-T eclogite and blueschist derived grains (grey field, Fig. 3). But

242 by doing so, we increase the interval of confidence in this assessment, as we do not include

243 false positives (such as grains formed at higher T/P conditions). If we were to use a different

244 filter (pink star, Fig. 3), we could inevitably include more eclogite facies-derived grains (low

245 T/P), but we would introduce uncertainty from potential HP amphibolite facies-derived grains

246 (intermediate T/P).

A pressure of $13 \mathrm{kbar}$ was applied to all grains in the dataset, and uncertainties on this selected pressure ( $2 \mathrm{kbar}$ ) are propagated in quadrature. We consider $\mathrm{Zr}$ measurement uncertainty, the calibration uncertainty, and the weighted mean average of the standard deviation of temperature calculated based on all rutile grains from single metamorphic rocks to calculate the final uncertainty (see below). Together, these should account for both Zr-inrutile variability in natural rocks, and for the analytical uncertainties. A minimum $10-15{ }^{\circ} \mathrm{C}$ uncertainty in the calibration is reported from Kohn (2020), while in the literature there is a discussion of the effects on a-quartz activity in the temperature estimate that can amount to about $50-100{ }^{\circ} \mathrm{C}$ (that does not affect the metafelsic-derived grains). On average, the propagated natural variance uncertainty amounts to around $3 \%$. We use this value (natural variance) to propagate uncertainties on each single-grain analysis as follows:

$$
\operatorname{TZr} r u t \pm=\sqrt{(\text { natural variance })^{2}+(Z r \text { precision })^{2}+(P \pm)^{2}}
$$

By applying a $13 \mathrm{kbar}$ pressure to the entire dataset, in order to better estimate the

260 low temperature end, we bias most of the higher $\mathrm{Zr}$ concentrations in rutile towards the

261 "amphibolite" facies conditions field (Fig. 3 - following the isopleths from eclogite facies 
$600 \mathrm{ppm} \operatorname{Zr}\left(750^{\circ} \mathrm{C}\right)$, when recalculated at $13 \mathrm{kbar}$ yields a $670^{\circ} \mathrm{C}$ estimate and will plot in

264 the intermediate T/P field (Fig. 3). The opposite occurs with low-P granulite rutile grains (< $26510 \mathrm{kbar}$, formed under high T/P) when recalculated to $13 \mathrm{kbar}$. Yet, this $\mathrm{P}$ variance is 266 restricted to ca. $5 \mathrm{kbar}$, and thus it might only account for a small T variation (sometimes 267 enclosed within all the propagated uncertainties; $<30^{\circ} \mathrm{C}$; Fig. 3). Therefore, we do not discuss in any particular detail the variance seen in the high-grade metamorphic realm, as

269 this variance reflects several competing factors, but it does indicate the presence of high270 grade rutile and thus of high T/P.

\section{4. ASSESSING THE METAMORPHIC RECORD BY UTILISING DETRITAL RUTILE}

272 4.1. Detrital rutile grains nature: discriminating sources

273 As mentioned in section 1, rutile can grow after metamorphic reactions, in a wide range of 274 bulk rock compositions, or associated to magmatic and fluid precipitating processes. To 275 retrieve peak-T estimates from the Zr-in-rutile geothermometer, rutile grains were screened 276 to assess the process by which they were formed. High field strength elements (HFSE), Sn 277 and $\mathrm{W}$ can be used to distinguish some of these different rutile growth processes (Agangi et 278 al., 2019; Pereira et al., 2019). Some key features of magmatic-related rutile include very 279 high W, Sn, Sb and Nb concentrations (e.g. Meinhold et al., 2010; Agangi et al., 2019) or 280 very high $\mathrm{Nb} / \mathrm{Ta}$ ratios. Rutile is also known to form in ore mineralisation settings yielding 281 very high $\mathrm{Sb} / \mathrm{V}, \mathrm{Sn}, \mathrm{Sb}$ and $\mathrm{W}$. Authigenic rutile and/or rutile related to low-T fluids yields low

$282 \mathrm{Nb} / \mathrm{Ta}$ ratios, as Ta becomes more compatible with rutile in the presence of aqueous fluids, combined with low $\mathrm{Zr} / \mathrm{Hf}$ ratios (Pereira et al., 2019). Because published analyses of detrital rutile usually lack full trace element composition reporting, only a small fraction of the available $\mathrm{U}-\mathrm{Pb}$ detrital rutile data could be included in this work. 
areas $\left(n_{\text {rut }}=245\right)$ and are combined with extensive published data, making it a rather comprehensive study. In Pereira et al. (2019), the fluid-related field is based on 3 samples from a single unit $\left(\mathrm{n}_{\mathrm{rut}}=50\right)$, presented together with data from another study reporting authigenic rutile and combined with published metamorphic rutile data $\left(n_{\text {tot }}=453\right)$. These boundaries might be broader than depicted in Figure 4, and future studies might better refine these. Still, by combining these different discriminating diagrams, we preclude, as most as possible, inclusion of low-T and -P rutile, as well as magmatic-related rutile grains. mostly lack inclusions. No inclusions of sulphides or extreme porosity were observed, such as commonly reported in rutile from ore deposit settings (Scott and Radford, 2007; Scott et al., 2011; Agangi et al., 2019; Pereira et al., 2019; appendix 4). Published studies also reported similar textures and included only chemically homogeneous grains. Trace elementbased discrimination diagrams were applied to our dataset (Fig. 4). The majority of rutile grains yield $\mathrm{Nb} / \mathrm{Ta}$ and $\mathrm{Zr} / \mathrm{Hf}$ values commonly found in metamorphic settings, although a few grains yield very low or high $\mathrm{Nb} / \mathrm{Ta}$ values (Fig. 4A). Most rutile grains yield $\mathrm{Sn}$ and $\mathrm{W}$ concentrations below 1000 ppm (Fig. 4B, C) and Sb values under 20 ppm (Fig. 4D). Some published data show $\mathrm{Sn} / \mathrm{Sb}-\mathrm{W}$ values compatible with magmatic-related or Au-mineralised sources. Generally, rutile grains included in this study have low Sb/V (Fig. 4C) suggesting that even when Sn-W are more elevated (Fig. 4B), the rutile grains are of a metamorphic origin (Fig. 4).

We excluded grains that plot in the fluid-related or magmatic fields, which reduced

309 the dataset from 840 to 735 (appendix 2). Therefore, the resulting dataset includes only

310 grains that grew from metamorphic reactions, and thus can be used to infer metamorphic 311 conditions. 
313 Each datapoint displayed on Figure 5 has been calculated using Kohn (2020) Zr-in-rutile

314 combined equation and a pressure of $13 \mathrm{kbar}$, following the discussion in section 3 . Despite

315 the natural bias in assuming a given temperature, the uncertainties associated with it

316 (discussed in section 3 and that for high T/P rocks it can amount to an overestimation of 30

$317^{\circ} \mathrm{C}$ ) still allow us to draw conclusions regarding the existence of very high, moderately high

318 or low temperature rutile. Rutile temperature data show periods with a wide range,

319 separated by periods of more uniform growth temperatures (Fig. 5) that correspond to

320 events within the supercontinental cycle (e.g. Brown and Johnson, 2019). Periods showing

321 the widest variations in peak metamorphic temperatures occur between 0.3 and $0.55 \mathrm{Ga}, 1.0$

322 and $1.2 \mathrm{Ga}$, and 1.7 and $2.1 \mathrm{Ga}$, corresponding with periods of supercontinent assembly and

323 collisional orogenesis. A significant number of detrital rutile yield temperatures above 850

$324{ }^{\circ} \mathrm{C}$, which despite the method used for its determination, are only compatible with rutile

325 formed at granulite facies conditions. These take place during assembly of the Gondwana-

326 Pangea, Nuna and Kenor supercontinents (Fig. 5).

Few rutile grains record peak temperatures lower than $550^{\circ} \mathrm{C}(\mathrm{n}=31)$ or than $580^{\circ} \mathrm{C}$ $(n=62)$, and the majority of these low T rutile are Phanerozoic in age (Fig. 5). Although the data offers no insight into the geothermal gradient at any particular time, as they overlap with the different T/P fields from (Brown and Johnson, 2018), we can directly link estimated peak temperatures with the geothermal gradient index (Fig. 5). These wide temperature variations are compatible with those described for paired metamorphic belts (Brown and Johnson, 2018), indicating quite different metamorphic grades in rocks of the same age. In the Carboniferous and in the Ediacaran where low and high T/P are known, our dataset shows evidence of low- and high-T rutile (and hence low and high $T / P$ ), tying together the metamorphic rock and rutile record, and reinforcing the suitability of this approach in probing earlier periods. From this small detrital rutile dataset, we obtained a few low T rutile grains between 1.0 and $1.2 \mathrm{Ga}$, and also between 1.7 and $2.2 \mathrm{Ga}$ (Fig. 5). We note that those low T/P rutile grains have the same provenance as some of those derived from higher T/P. 
340 Therefore, this new approach and dataset confirm the existence of low TIP and paired

341 metamorphism during the late Palaeoproterozoic and late Mesoproterozoic, during both

342 Nuna and Rodinia assembly, as well as in the Neoproterozoic to Palaeozoic during

343 Gondwana and then Pangea assemblies. The number of cases recording Rodinia assembly

344 are few in comparison to Gondwana-Pangea or Nuna, and they only record tectonometamorphic processes from the Grenville Province on east Laurentia (Pereira et al.,

346 2020). U-Pb and $\mathrm{Zr}$ resetting of rutile have been reported in other studies (Zack and

347 Kooijman, 2017) and show that $\mathrm{Pb}$ diffuses much faster than $\mathrm{Zr}$. Full resetting of the U-Pb

348 system in rutile in these cases would imply the existence of such conditions prior to the late

349 Palaeoproterozoic. Indeed, a few rutile grains with ages between 2.3 and 2.55 Ga yield temperature estimates between 550 and $580^{\circ} \mathrm{C}$ but not lower. No older, Archaean rutile grains selected in this study yield low-T indicative of a low T/P gradient (Fig. 5), but more data are required to confirm this observation.

\section{Preservation Bias of the Exposed Metamorphic Crust and 'Paired' Metamorphism}

354 In this new compilation of detrital rutile data, we have probed the sedimentary record in the search for low T/P metamorphism by applying the Zr-in-rutile geothermometer to detrital metamorphic rutile covering most of Earth's history. We show that both low and high T/P conditions can be inferred since at least 2.1 Ga. The absence of Archaean rutile grains yielding $<550{ }^{\circ} \mathrm{C}$ is consistent with the absence of low T/P rocks of this age in the Archaean geological record (Brown and Johnson, 2019). Despite the relatively restricted number of low-T eclogite occurrences of Proterozoic age, our relatively small dataset show that these conditions prevailed. Thus, the lack of preserved blueschists and low-T eclogites prior to the Neoproterozoic represents a preservation bias that can be probably linked to retrogression and overprinting of HP-UHP units at suture zones and to the small stability fields of some indicator minerals (e.g. lawsonite). We argue that metamorphic rutile, preserved as detrital grains in the sedimentary record, can track low and high/intermediate T/P conditions through time. Applied to a given basin and using detrital grains of similar age, it can also provide the 
367 missing evidence of paired metamorphic conditions over time, which is envisaged as a

368 hallmark of sustained subduction zones in modern plate tectonics. Our data show that both 369 during Rodinia and Nuna assemblies, rutile grains show this dual low and high T/P and thus

370 that modern plate tectonics has been operating since at least the late Palaeoproterozoic,

371 shaping and conditioning the evolution of the continental crust. Furthermore, the absence of

372 low $\mathrm{T} / \mathrm{P}$ conditions $\left(\mathrm{T}<550^{\circ} \mathrm{C}\right)$ in the late Archaean, both from the detrital rutile and rock

373 records, suggests that contrasting mechanisms were operating during continental assembly

374 at that time. However, some detrital rutile with late Archean, early Palaeoproterozoic age

375 yield growth temperatures between 550 and $580^{\circ} \mathrm{C}$, many of which are of metamafic affinity.

376 In quartz-absent rocks, $\mathrm{Zr}$ will be preferentially taken by rutile, implying that by applying the

377 Zr-in-rutile thermometer calibrated for $a_{\alpha-q u a r t z}=1$ we are overestimating the temperature.

378 Since there is no other line of evidence to assist in $a_{\alpha-q u a r t z}$ estimation at the time of rutile

379 growth, we can not ascertain if these temperatures are overestimated, but it leads to an

380 open possibility that low T/P subduction could have taken place at the end of the Archean.

381 More detrital rutile data yielding those ages are thus required.

\section{CONCLUSIONS}

383 To investigate metamorphic conditions through time, we have looked at detrital rutile

384 preserved in the sedimentary record as a tracer of past metamorphic conditions. Rutile

385 yielding temperatures lower than $550-580^{\circ} \mathrm{C}$ is linked to low T/P conditions, which together

386 with very high temperature detrital rutile and the rock record can be used to infer the

387 presence of paired metamorphic conditions and tectonic processes through time.

While the likely transition between early Earth geodynamics and the onset of subduction seems to have been diachronous as recorded on different cratons (Cawood et

390 al., 2018; Laurent et al., 2014), we suggest that it is the youngest evidence of this transition

391 that serves as evidence of a completed switch to modern plate tectonics, with an

392 interconnected plate boundary system operating worldwide. 
394 2018; Dhuime et al., 2012) and the last appearance of a TTG to sanukitoid transition culminates at $2.13 \mathrm{Ga}$ (Moreira et al., 2020, 2018). This final transition is marked by the first appearance of low T/P and paired metamorphism, as recorded by detrital rutile, in agreement with a few retro-eclogite occurrences with this age (see Brown et al., 2019 for references, and Holder et al., 2019). This transition is also manifested in the current crustal structure of several Palaeoproterozoic age belts, where recent seismological data is consistent with development of a palaeo-subduction network by ca. 2 Ga (Wan et al., 2020) and also with the oldest preserved linked linear orogenic belts of Eburnean age (Condie, 2013). Thus, although the metamorphic rock record is envisaged as supporting a major change in geodynamics at the dawn of the Phanerozoic after a protracted transition (Brown et al., 2020; Brown and Johnson, 2018; Stern, 2005), we contend that the preserved rock record indicates that the onset of modern plate tectonics took place during the late Palaeoproterozoic. By using sedimentary rocks as an archive of the continental crust we have started to contribute towards a more complete overview of the low T/P metamorphic conditions through time and of its forcing mechanisms.

\section{ACKNOWLEDGEMENTS}

410 We would like to thank Geoff Long for amazing technical support during sample preparation 411 and Mike Dunk for assistance during sampling. We thank Michael Brown for his valuable

412 comments on an earlier version of this manuscript. We are also thankful to Matthew Kohn 413 and an anonymous reviewer for their constructive comments during peer-review and Alex

414 Webb for his editorial handling. Funding: IP wants to thank the University of Portsmouth for 415 providing a PhD bursary, technical support and for funding all analytical work. HM thanks 416 CNPq - Brazil grant 234610/2014-0. PAC acknowledges support from Australian Research 417 Council grant FL160100168.

\section{REFERENCES CITED}


419 Agangi, A., Plavsa, D., Reddy, S.M., Olierook, H., Kylander-Clark, A., 2020. Compositional 420 modification and trace element decoupling in rutile: Insight from the Capricorn Orogen, $421 \quad$ Western Australia. Precambrian Res. 345, 105772. https://doi.org/10.1016/j.precamres.2020.105772

Agangi, A., Reddy, S.M., Plavsa, D., Fougerouse, D., Clark, C., Roberts, M., Johnson, T.E., 2019. Antimony in rutile as a pathfinder for orogenic gold deposits. Ore Geol. Rev. 106,

Angiboust, S., Harlov, D., 2017. Ilmenite breakdown and rutile-titanite stability in metagranitoids: Natural observations and experimental results. Am. Mineral. 102, 1696-1708. https://doi.org/10.2138/am-2017-6064

Brown, M., Johnson, T., 2019. Time's arrow, time's cycle: Granulite metamorphism and geodynamics. Mineral. Mag. 83, 323-338. https://doi.org/10.1180/mgm.2019.19

Brown, M., Johnson, T., 2018. Secular change in metamorphism and the onset of global plate tectonics. Am. Mineral. 103, 181-196. https://doi.org/10.2138/am-2018-6166

Brown, Michael, Johnson, T., Gardiner, N.J., 2020. Plate Tectonics and the Archean Earth. Annu. Rev. Earth Planet. Sci. 48, 1-30. https://doi.org/10.1146/annurev-earth-081619-

Campbell, I.H., Squire, R.J., 2010. The mountains that triggered the Late Neoproterozoic increase in oxygen: The Second Great Oxidation Event. Geochim. Cosmochim. Acta 052705

Carruzzo, S., Clarke, D.B., Pelrine, K.M., MacDonald, M.A., 2006. Texture, composition, and 440 origin of rutile in the South Mountain Batholith, Nova Scotia. Can. Mineral. 44, 715-729. 74, 4187-4206. https://doi.org/10.1016/j.gca.2010.04.064 https://doi.org/10.2113/gscanmin.44.3.715

442 Cawood, P.A., Hawkesworth, C.J., Pisarevsky, S.A., Dhuime, B., Capitanio, F.A., Nebel, O., 
445 Condie, K.C., 2013. Preservation and recycling of crust during accretionary and collisional 446 phases of Proterozoic orogens: A bumpy road from Nuna to Rodinia. Geosciences, 3(2), 240-261. https://doi.org/10.3390/geosciences3020240

Condie, K.C., 2018. A planet in transition: The onset of plate tectonics on Earth between 3 and 2 Ga? Geosci. Front. 9, 51-60. https://doi.org/10.1016/j.gsf.2016.09.001

Cruz-Uribe, A.M., Feineman, M.D., Zack, T., Jacob, D.E., 2018. Assessing trace element 451 (dis)equilibrium and the application of single element thermometers in metamorphic rocks. Lithos 314-315, 1-15. https://doi.org/10.1016/j.lithos.2018.05.007

453 454 455

Dhuime, B., Hawkesworth, C.J., Cawood, P.A., Storey, C.D., 2012. A Change in the Geodynamics of Continental Growth 3 Billion Years Ago. Science (80-. ). 335, 1334 1337.

Dhuime, B., Hawkesworth, C.J., Delavault, H., Cawood, P.A., 2017. Continental growth seen through the sedimentary record. Sediment. Geol. 357, 16-32. https://doi.org/10.1016/j.sedgeo.2017.06.001

Flowerdew, M.J., Fleming, E.J., Morton, A.C., Frei, D., Chew, D.M., Daly, J.S., 2019. Assessing mineral fertility and bias in sedimentary provenance studies: examples from the Barents Shelf. Geol. Soc. London, Spec. Publ. SP484.11. https://doi.org/10.1144/sp484.11

François, C., Debaille, V., Paquette, J.L., Baudet, D., Javaux, E.J., 2018. The earliest evidence for modern-style plate tectonics recorded by HP-LT metamorphism in the Paleoproterozoic of the Democratic Republic of the Congo. Sci. Rep. 8, 1-10. https://doi.org/10.1038/s41598-018-33823-y 
467 Ganne, J., De Andrade, V., Weinberg, R.F., Vidal, O., Dubacq, B., Kagambega, N., Naba,

468 S., Baratoux, L., Jessell, M., Allibon, J., 2012. Modern-style plate subduction preserved 469 in the Palaeoproterozoic West African craton. Nat. Geosci. 5, 60-65.

$470 \quad$ https://doi.org/10.1038/ngeo1321

471 Gao, X.Y., Zheng, Y.F., Xia, X.P., Chen, Y.X., 2014. U-Pb ages and trace elements of 472 metamorphic rutile from ultrahigh-pressure quartzite in the Sulu orogen. Geochim. Cosmochim. Acta 143, 87-114. https://doi.org/10.1016/j.gca.2014.04.032

474 Gonçalves, G.O., Lana, C., Buick, I.S., Alkmim, F.F., Scholz, R., Queiroga, G., 2019. Twenty 475 million years of post-orogenic fluid production and hydrothermal mineralization across 476 the external Araçuaí orogen and adjacent São Francisco craton, SE Brazil. Lithos 342477 343, 557-572. https://doi.org/10.1016/j.lithos.2019.04.022

Hart, E., Storey, C., Bruand, E., Schertl, H.P., Alexander, B.D., 2016. Mineral inclusions in 479 480 rutile: A novel recorder of HP-UHP metamorphism. Earth Planet. Sci. Lett. 446, 137148. https://doi.org/10.1016/j.epsl.2016.04.035

481

Jochum, K.P., Weis, U., Stoll, B., Kuzmin, D., Yang, Q., Raczek, I., Jacob, D.E., Stracke, A., 482 Birbaum, K., Frick, D.A., Günther, D., Enzweiler, J., 2011. Determination of reference values for NIST SRM 610-617 glasses following ISO guidelines. Geostand.

Jochum, K.P., Willbold, M., Raczek, I., Stoll, B., Herwig, K., 2005. Chemical Characterisation 486 of the USGS Reference Glasses and BIR-1G Using EPMA , ID-TIMS , ID-ICP-MS and LA-ICP-MS. Geostand. Geoanalytical Res. 29, 285-302. https://doi.org/10.1111/j.1751-

Kohn, M.J., 2020. A refined zirconium-in-rutile thermometer. Am. Mineral. 105, 963-971. 
491

492

493

494

495

496

497

498

499

500

501

502

503

504

505

506

507

508

509

510

511

512

513

514

Kotková, J., Harley, S.L., 2010. Anatexis during high-pressure crustal metamorphism: Evidence from garnet-whole-rock REE relationships and zircon-rutile Ti-Zr thermometry in leucogranulites from the Bohemian Massif. J. Petrol. 51, 1967-2001. https://doi.org/10.1093/petrology/egq045

Kusky, T., 2020. Plate tectonics in relation to mantle temperatures and metamorphic properties. Sci. China Earth Sci. 63, 634-642. https://doi.org/10.1007/s11430-020$9597-5$

Laurent, O., Martin, H., Moyen, J.F., Doucelance, R., 2014a. The diversity and evolution of late-Archean granitoids: Evidence for the onset of "modern-style" plate tectonics between 3.0 and 2.5Ga. Lithos 205, 208-235. https://doi.org/10.1016/j.lithos.2014.06.012

Laurent, O., Martin, H., Moyen, J.F., Doucelance, R., 2014b. The diversity and evolution of late-Archean granitoids: Evidence for the onset of "modern-style" plate tectonics between 3.0 and $2.5 \mathrm{Ga}$. Lithos 205, 208-235. https://doi.org/10.1016/j.lithos.2014.06.012

Lenardic, A., 2018. The diversity of tectonic modes and thoughts about transitions between them. Philos. Trans. R. Soc. A Math. Phys. Eng. Sci. 376. https://doi.org/10.1098/rsta.2017.0416

Li, X. hua, Wei, G., Shao, L., Liu, Y., Liang, X., Jian, Z., Sun, M., Wang, P., 2003. Geochemical and Nd isotopic variations in sediments of the South China Sea: A response to Cenozoic tectonism in SE Asia. Earth Planet. Sci. Lett. 211, 207-220. https://doi.org/10.1016/S0012-821X(03)00229-2 
515 Liou, J.G., Zhang, R., Ernst, W.G., Liu, J., McLimans, R., 1998. Mineral parageneses in the

516 Piampaludo eclogitic body, Gruppo di Voltri, western Ligurian Alps. Schweizerische

$517 \quad$ Mineral. und Petrogr. Mitteilungen 78, 317-335.

518 Lombardo, B., Rolfo, F., 2000. Two contrasting eclogite types in the Himalayas: Implications

519 for the Himalayan orogeny. J. Geodyn. 30, 37-60. https://doi.org/10.1016/S0264-

$520 \quad 3707(99) 00026-5$

521 Luvizotto, G.L., Zack, T., Triebold, S., Von Eynatten, H., 2009. Rutile occurrence and trace

522 element behavior in medium-grade metasedimentary rocks: Example from the

523 Erzgebirge, Germany. Mineral. Petrol. 97, 233-249. https://doi.org/10.1007/s00710-

$524 \quad$ 009-0092-z

525 Meinhold, G., Anders, B., Kostopoulos, D., Reischmann, T., 2008. Rutile chemistry and

526 thermometry as provenance indicator: An example from Chios Island, Greece.

527 Sediment. Geol. 203, 98-111. https://doi.org/10.1016/j.sedgeo.2007.11.004

528 Moreira, H., Seixas, L., Storey, C., Fowler, M., Lasalle, S., Stevenson, R., Lana, C., 2018.

529 Evolution of Siderian juvenile crust to Rhyacian high Ba-Sr magmatism in the Mineiro

$530 \quad$ Belt, southern São Francisco Craton. Geosci. Front. 9, 977-995.

$531 \quad$ https://doi.org/10.1016/j.gsf.2018.01.009

532 Moreira, H., Storey, C., Fowler, M., Seixas, L., Dunlop, J., 2020. Petrogenetic processes at 533 the tipping point of plate tectonics: Hf-O isotope ternary modelling of Earth's last TTG to 534 sanukitoid transition. Earth Planet. Sci. Lett. 551, 116558.

$535 \quad$ https://doi.org/10.1016/j.epsl.2020.116558

536 Pape, J., Mezger, K., Robyr, M., 2016. A systematic evaluation of the Zr-in-rutile

537 thermometer in ultra-high temperature (UHT) rocks. Contrib. to Mineral. Petrol. 171.

$538 \quad$ https://doi.org/10.1007/s00410-016-1254-8 
539 Pereira, I., Storey, C., Darling, J., Lana, C., Alkmim, A.R., 2019. Two billion years of

540 evolution enclosed in hydrothermal rutile: Recycling of the São Francisco Craton Crust

541 and constraints on gold remobilisation processes. Gondwana Res. 68, 69-92.

$542 \quad$ https://doi.org/10.1016/j.gr.2018.11.008

543 Pereira, I., Storey, C.D., Strachan, R.A., Bento dos Santos, T., Darling, J.R., 2020. Detrital

544 rutile ages can deduce the tectonic setting of sedimentary basins. Earth Planet. Sci.

$545 \quad$ Lett. 537, 116193. https://doi.org/10.1016/j.epsl.2020.116193

546 Province, B., Shield, F., Melnik, A.E., Skublov, S.G., Rubatto, D., Müller, D., Li, X., Li, Q.,

547 Berezin, A. V, Herwartz, D., Machevariani, M.M., 2021. Garnet and zircon

548 geochronology of the Paleoproterozoic Kuru-Vaara. Precambrian Res. 353, 106014.

$549 \quad$ https://doi.org/10.1016/j.precamres.2020.106014

550 Reinhard, C.T., Planavsky, N.J., Gill, B.C., Ozaki, K., Robbins, L.J., Lyons, T.W., Fischer,

551 W.W., Wang, C., Cole, D.B., Konhauser, K.O., 2017. Evolution of the global

552 phosphorus cycle. Nature 541, 386-389. https://doi.org/10.1038/nature20772

553 Rösel, D., Zack, T., Boger, S.D., 2014. LA-ICP-MS U-Pb dating of detrital rutile and zircon

554 from the Reynolds Range: A window into the Palaeoproterozoic tectonosedimentary

555 evolution of the North Australian Craton. Precambrian Res. 255, 381-400.

556 https://doi.org/10.1016/j.precamres.2014.10.006

557 Rösel, D., Zack, T., Möller, A., 2018. Interpretation and significance of combined trace

558 element and $\mathrm{U}-\mathrm{Pb}$ isotopic data of detrital rutile: a case study from late Ordovician

559 sedimentary rocks of Saxo-Thuringia, Germany. Int. J. Earth Sci. 0, 0.

$560 \quad$ https://doi.org/10.1007/s00531-018-1643-5

561 Şengün, F., Zack, T., Dunkl, I., 2020. Provenance of detrital rutiles from the Jurassic

562 sandstones in the Central Sakarya Zone, NW Turkey: U-Pb ages and trace element

563 geochemistry. Chemie der Erde. https://doi.org/10.1016/j.chemer.2020.125667 
564 Skelton, A., Peillod, A., Glodny, J., Klonowska, I., Månbro, C., Lodin, K., Ring, U., 2019.

565 Preservation of high-P rocks coupled to rock composition and the absence of

566 metamorphic fluids. J. Metamorph. Geol. 37, 359-381.

$567 \quad$ https://doi.org/10.1111/jmg.12466

568 Spear, F.S., Wark, D.A., Cheney, J.T., Schumacher, J.C., Watson, E.B., 2006. Zr-in-rutile 569 thermometry in blueschists from Sifnos, Greece. Contrib. to Mineral. Petrol. 152, 375$570 \quad 385$. https://doi.org/10.1007/s00410-006-0113-4

571 Stern, R.J., 2005. Evidence from ophiolites, blueschists, and ultrahigh-pressure 572 metamorphic terranes that the modern episode of subduction tectonics began in Neoproterozoic time. Geology 33, 557-560. https://doi.org/10.1130/G21365.1

574 Tomkins, H.S., Powell, R., Ellis, D.J., 2007. The pressure dependence of the zirconium-in575 rutile thermometer. J. Metamorph. Geol. 25, 703-713. https://doi.org/10.1111/j.1525$576 \quad 1314.2007 .00724 . x$

577 Triebold, S., von Eynatten, H., Luvizotto, G.L., Zack, T., 2007. Deducing source rock 578 lithology from detrital rutile geochemistry: An example from the Erzgebirge, Germany. 579 Chem. Geol. 244, 421-436. https://doi.org/10.1016/j.chemgeo.2007.06.033

580 Triebold, S., von Eynatten, H., Zack, T., 2012. A recipe for the use of rutile in sedimentary 581 provenance analysis. Sediment. Geol. 282, 268-275.

582 https://doi.org/10.1016/j.sedgeo.2012.09.008

Tsujimori, T., Sisson, V.B., Liou, J.G., Harlow, G.E., Sorensen, S.S., 2006. Very-lowtemperature record of the subduction process: A review of worldwide lawsonite eclogites. Lithos 92, 609-624. https://doi.org/10.1016/j.lithos.2006.03.054 evidence for the earliest global subduction network at 2 Ga ago. Sci. Adv. 6, eabc5491. 
589

590

591

592

593

594

595

596

597

598

599

600

601

602

603

604

605

606

607

608

609

Weller, O.M., St-Onge, M.R., 2017. Record of modern-style plate tectonics in the Palaeoproterozoic Trans-Hudson orogen. Nat. Geosci. 10, 305-311. https://doi.org/10.1038/ngeo2904

Whitney, D.L., Davis, P.B., 2006. Why is lawsonite eclogite so rare? Metamorphism and preservation of lawsonite eclogite, Sivrihisar, Turkey. Geology 34, 473-476. https://doi.org/10.1130/G22259.1

Zack, T., Kooijman, E., 2017. Petrology and Geochronology of Rutile. Rev. Mineral. Geochemistry 83, 443-467. https://doi.org/10.2138/rmg.2017.83.14

Zack, T., Moraes, R., Kronz, A., 2004a. Temperature dependence of Zr in rutile: Empirical calibration of a rutile thermometer. Contrib. to Mineral. Petrol. 148, 471-488. https://doi.org/10.1007/s00410-004-0617-8

Zack, T., von Eynatten, H., Kronz, A., 2004b. Rutile geochemistry and its potential use in quantitative provenance studies. Sediment. Geol. 171, 37-58. https://doi.org/10.1016/j.sedgeo.2004.05.009

Zerkle, A.L., 2018. Biogeodynamics: Bridging the gap between surface and deep Earth processes. Philos. Trans. R. Soc. A Math. Phys. Eng. Sci. 376. https://doi.org/10.1098/rsta.2017.0401

Zhou, G., Fisher, C.M., Luo, Y., Pearson, D.G., Li, L., He, Y., Wu, Y., 2020. A clearer view of crustal evolution: $\mathrm{U}-\mathrm{Pb}, \mathrm{Sm}-\mathrm{Nd}$, and $\mathrm{Lu}-\mathrm{Hf}$ isotope systematics in five detrital minerals unravel the tectonothermal history of northern China. GSA Bull. 1-15. https://doi.org/10.1130/b35515.1 


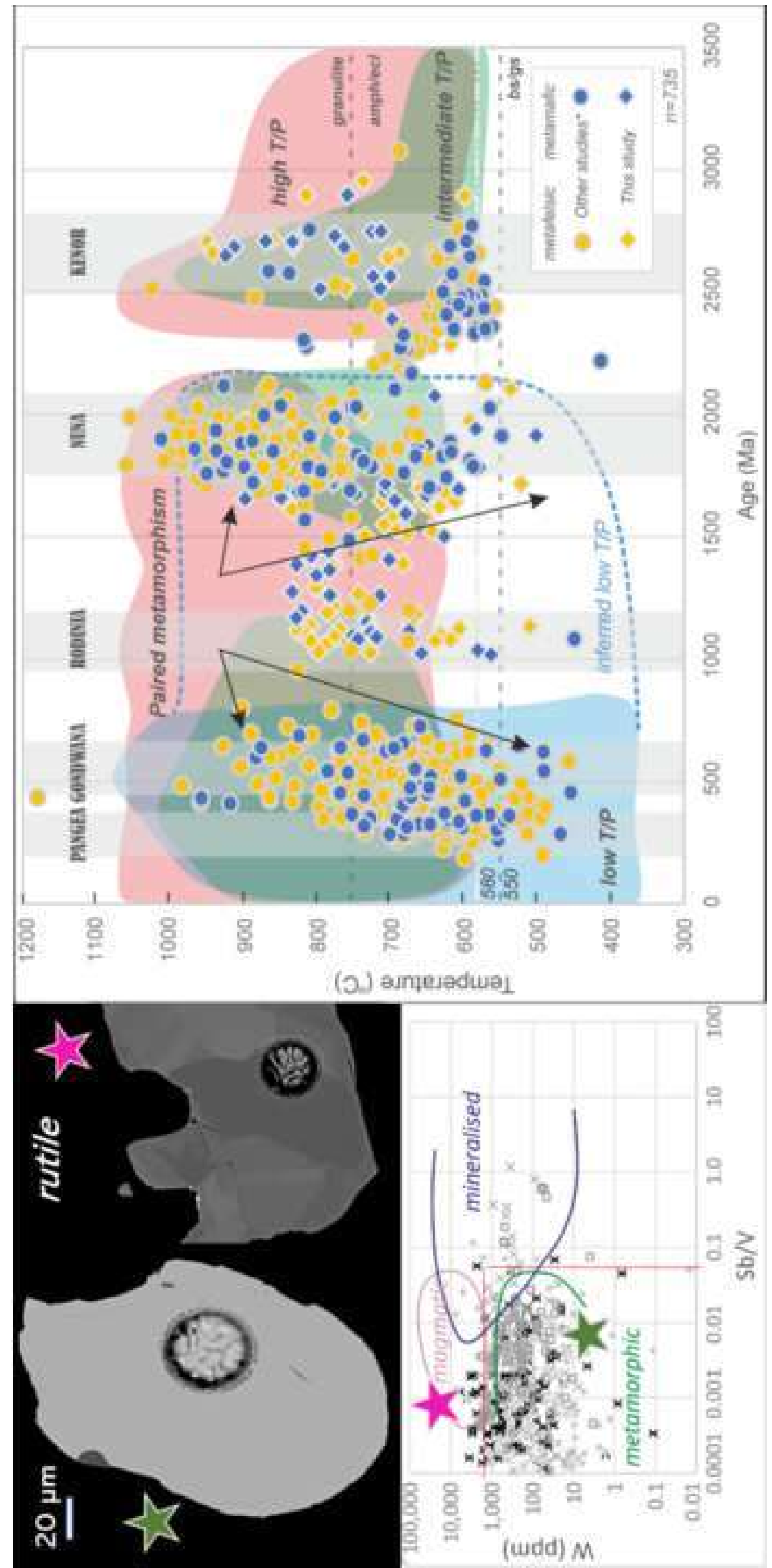


Figure 1. Comparison between temperature estimates based on $\mathrm{Zr}$-in-rutile (Kohn, 2020) and on mineral equilibria for 45 samples from 14 published studies (appendix 1). For $\mathrm{Zr}$-in-rutile estimates, average $\mathrm{Zr}$ concentrations were used. Uncertainty on the Zr-in-rutile temperatures was calculated using mineral equilibria determined pressure variation and the $\mathrm{Zr}$ concentration standard deviation of each sample. A) correlation between both methods using average estimates; $B$ ) correlation between both methods adjusting the temperature estimate of mineral equilibria taking into account its variation from classical thermometry.

Figure 2. Boxplot diagram depicting temperature estimates based on single grain Zr-in-rutile (Kohn, 2020) for multiple samples ( $n=52$ ), totalling 1123 rutile grains (appendix 1). Each Boxplot corresponds to a different sample, and data are coloured according to different metamorphic grade derived from the mineral assemblage. In cold colours, data derived from metamafic rocks, while warm colours from metafelsic rocks.

Figure 3. Temperature-Pressure diagram for Zr concentrations in rutile (isopleths in grey shades; Kohn 2020). In dashed blue, the minimum conditions for P-T path following low geothermal gradients, and in red, maximum for high geothermal gradients (from Palin et al., 2020). Orange lines correspond to the rutile-in reaction boundary in high silica system (granitoid composition similar to average pelite), the darker line corresponding to the most stable conditions at all given protolith compositions, while light orange to rutile occurrence under low $\mathrm{CaO}$ (1 wt\%) compositions (from Angiboust and Harlov, 2017). The black line corresponds to the boundary of blueschist to eclogite facies conditions (from Palin et al., 2020). Yellow star corresponds to the intersection of low T/P minimum conditions with the rutile-in reaction and $\mathrm{Zr}$ isopleth. This defines for a $100 \mathrm{ppm} \mathrm{Zr}$, at $13 \mathrm{kbar}, 550{ }^{\circ} \mathrm{C}$ maximum temperature filter. The dashed black triangle highlights the range of conditions that are ignored by applying a temperature filter to the data, which would still be considered low T/P-related conditions. The brown dashed lines correspond to estimates of diffusivity of $\mathrm{Zr}$ in rutile (from Cherniak et al., 2007). Each line can be used to interpret the effects of cooling rate or timescales of thermal overprinting-induced diffusion for $200 \mu \mathrm{m}$ grain sizes (which corresponds to the average of observed grain sizes in our samples). Very slow $\left(0.6{ }^{\circ} \mathrm{C} / \mathrm{Ma}\right)$, slow $\left(2.5^{\circ} \mathrm{C} / \mathrm{Ma}\right)$ or fast $\left(75{ }^{\circ} \mathrm{C} / \mathrm{Ma}\right)$ cooling rates of metamorphic terranes can lead to re-equilibration of $\mathrm{Zr}$ in rutile to equivalent concentrations of $600{ }^{\circ} \mathrm{C}, 650{ }^{\circ} \mathrm{C}$ or $800^{\circ} \mathrm{C}$, respectively. Thermal overprinting events can lead to $\mathrm{Zr}$ diffusion if thermal regimes overprint at higher than $600{ }^{\circ} \mathrm{C}$ for more than $50 \mathrm{Ma}$, than $650{ }^{\circ} \mathrm{C}$ if more than $10 \mathrm{Ma}$, and to $800^{\circ} \mathrm{C}$ for over 0.5 Ma. Pink star corresponds to conditions at which rutile could still be assigned as from T/P conditions, but with a lower level of confidence, if we also consider analytical/experimental uncertainties. The black field represents impossible high $\mathrm{P}$, low-T conditions on Earth.

Figure 4. Discrimination diagrams applied to detrital rutile (data can be found in appendix 2); a. based on $\mathrm{Zr} / \mathrm{Hf}$ and $\mathrm{Nb} / \mathrm{Ta}$ from (Pereira et al., 2019) with discriminative fields for low-P fluid-related, metamorphic s.s. and peridotite-related rutile. b., c., and d. based on $\mathrm{Sn}$ and $\mathrm{W}, \mathrm{W}$ an $\mathrm{Sb} / \mathrm{V}$, and $\mathrm{Sb}$ and $\mathrm{W}$ concentrations, respectively, from (Agangi et al., 2019) with discriminative fields for metamorphic sensu stricto, Au-mineralised related rutile and granitoid-related rutile. Symbols include measurement uncertainties as 1-sigma. Detrital rutile data used in this study to estimate temperatures plot within the metamorphic sensu stricto field of both diagrams. Dashed, red lines indicate filters applied for this discrimination.

Figure 5. The metamorphic record retrieved from the detrital archive; Metamorphic temperature estimates using the $\mathrm{Zr}$-in-rutile geothermometer at $13 \mathrm{kbar}$ (Kohn, 2020) versus detrital rutile U-Pb age; $\mathrm{n}=735$. For comparison, fields for low, high and intermediate T/P are plotted from (Brown and Johnson, 2018) and fields dividing temperature ranges for the different metamorphic facies (amph: amphibolite; ecl: eclogite; bs: blueschist; gs: greenschist). Dashed blue line corresponds to the new inferred field for low $T / P$ based on both the detrital rutile and rock record. Yellow symbols correspond to $\log (\mathrm{Cr} / \mathrm{Nb})<0$ and $\mathrm{Nb}>800 \mathrm{ppm}$ (metafelsic; $a_{\alpha-q u a r t z}=1$ ) whereas blue symbols correspond to $\log (\mathrm{Cr} / \mathrm{Nb})>0$ or $\mathrm{Nb}<800$ ppm (metamafic; $a_{\alpha-q u a r t z}=$ unknown) following (Meinhold et al., 2008). Data sources can be found in the text. 1-sigma data uncertainties fall within the symbol used for plotting. 


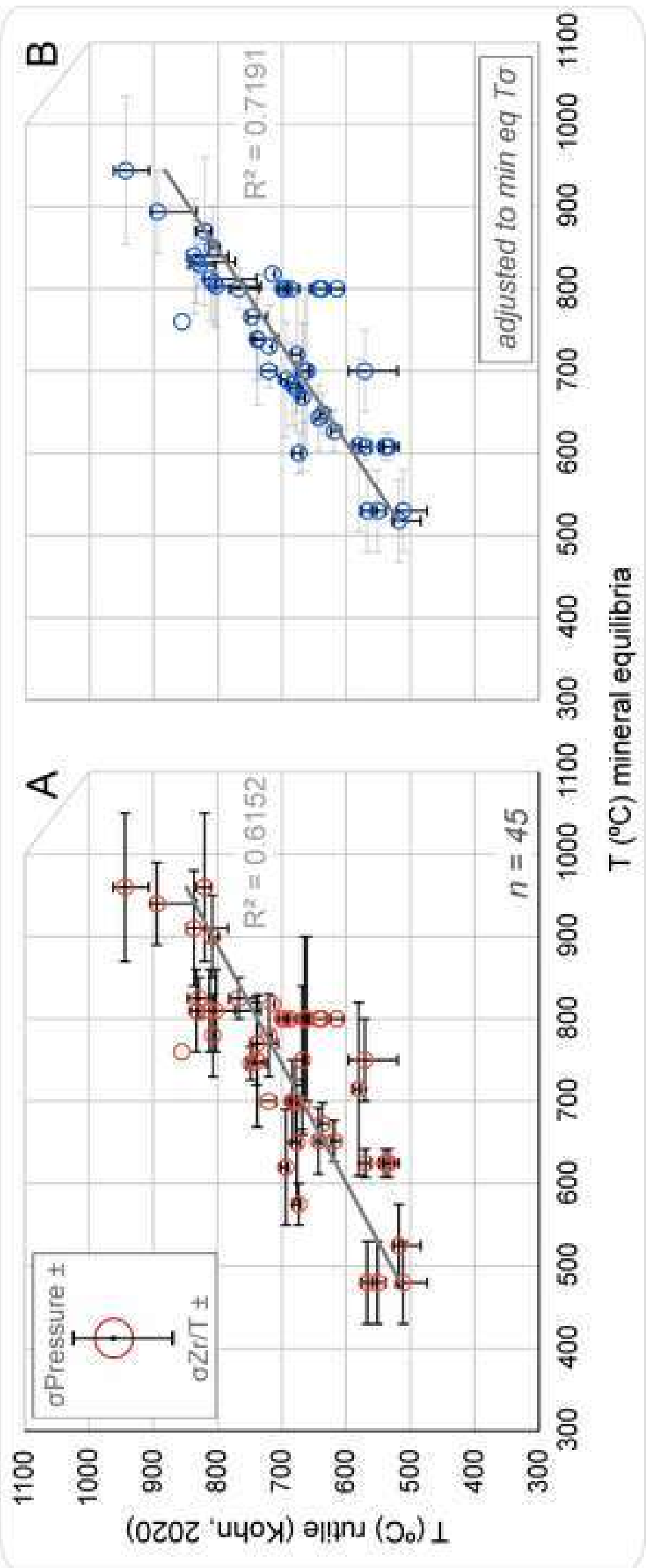




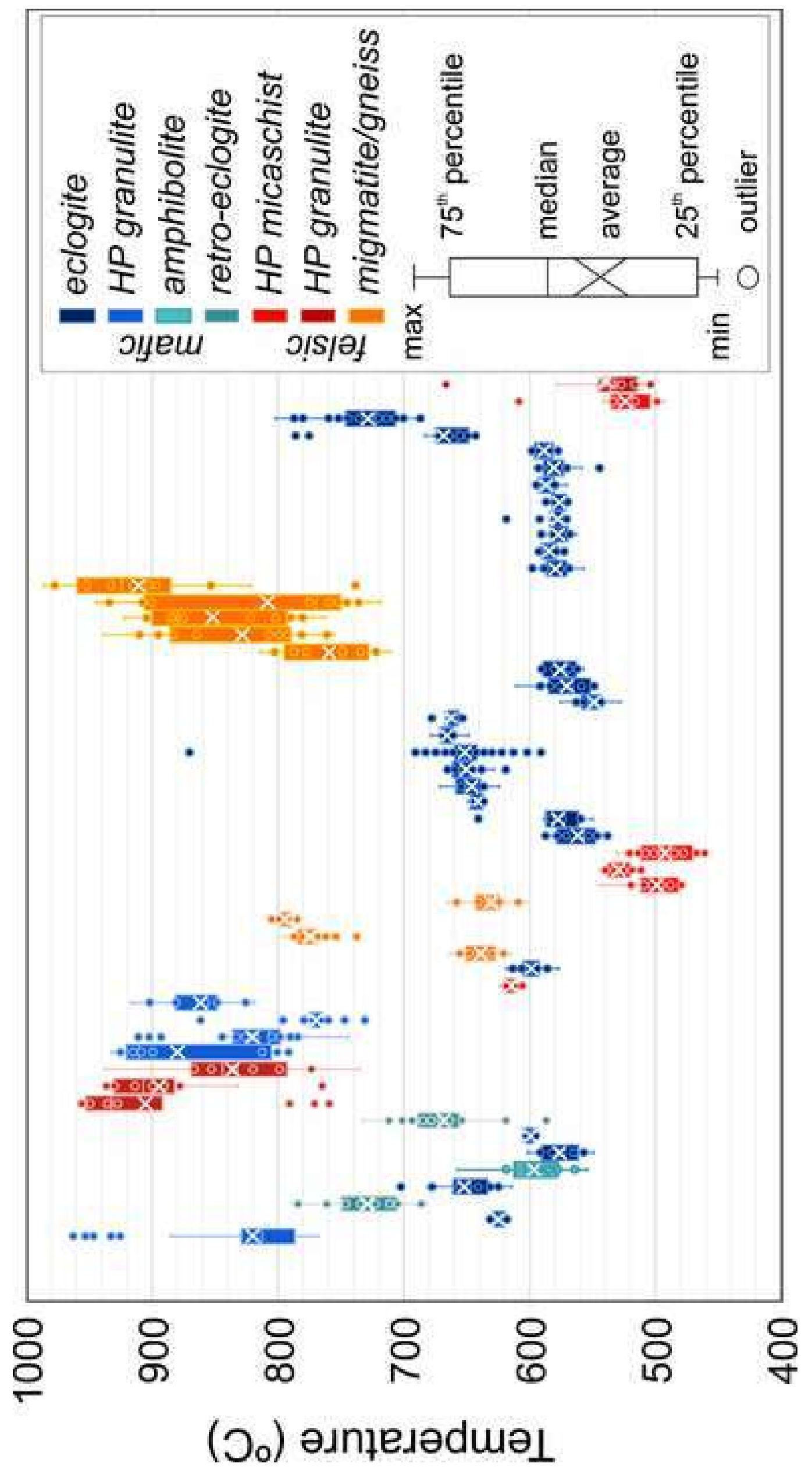




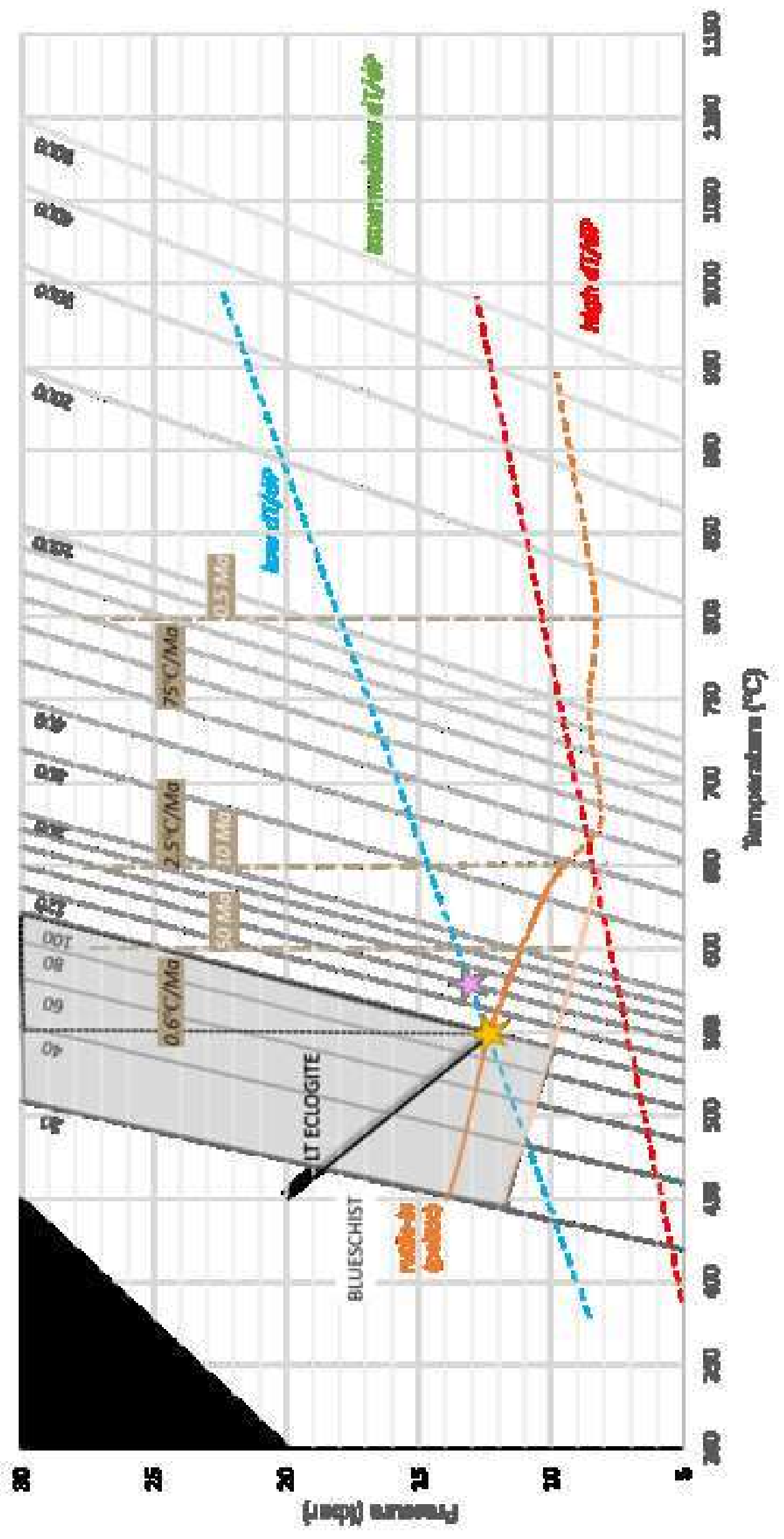



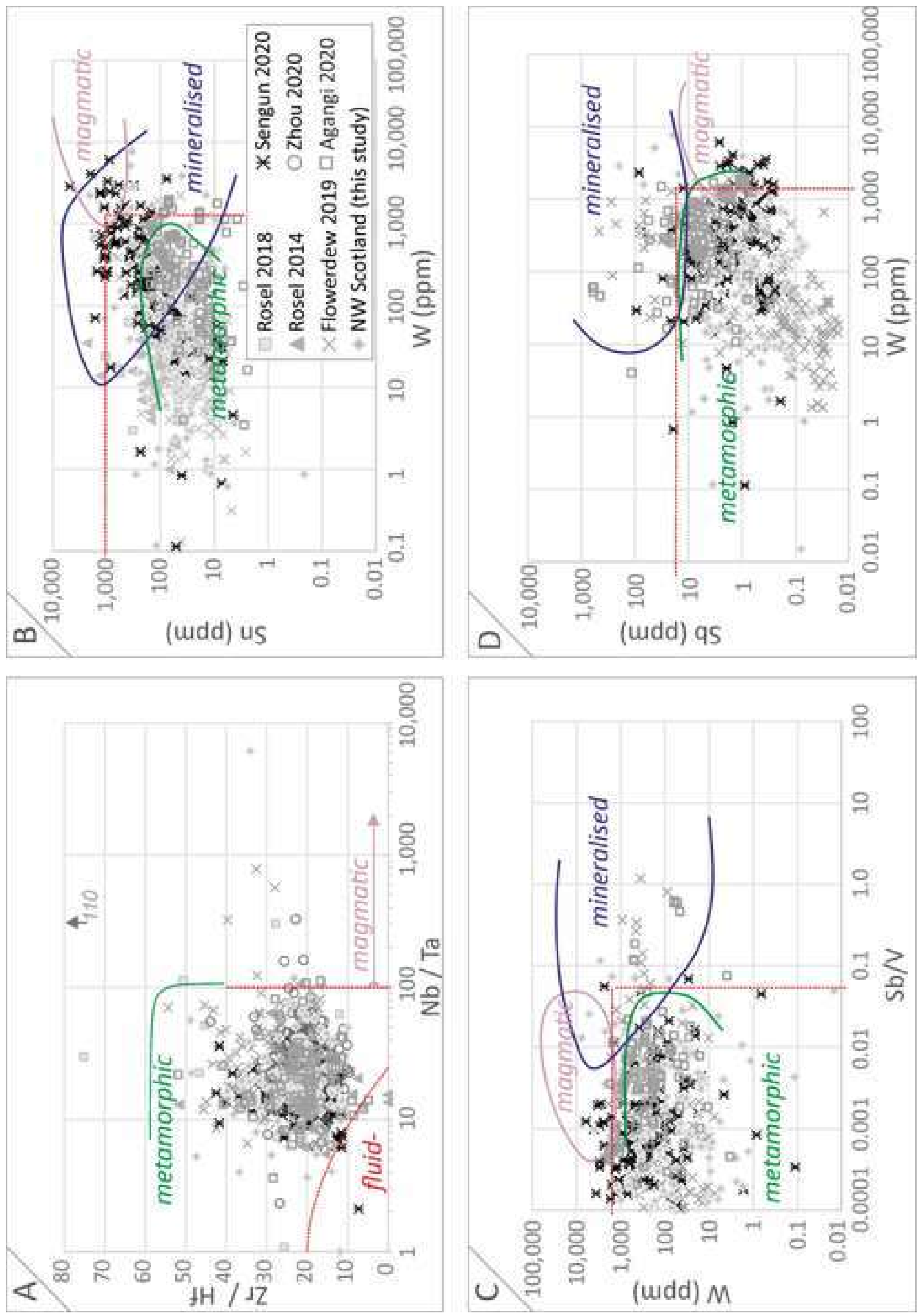


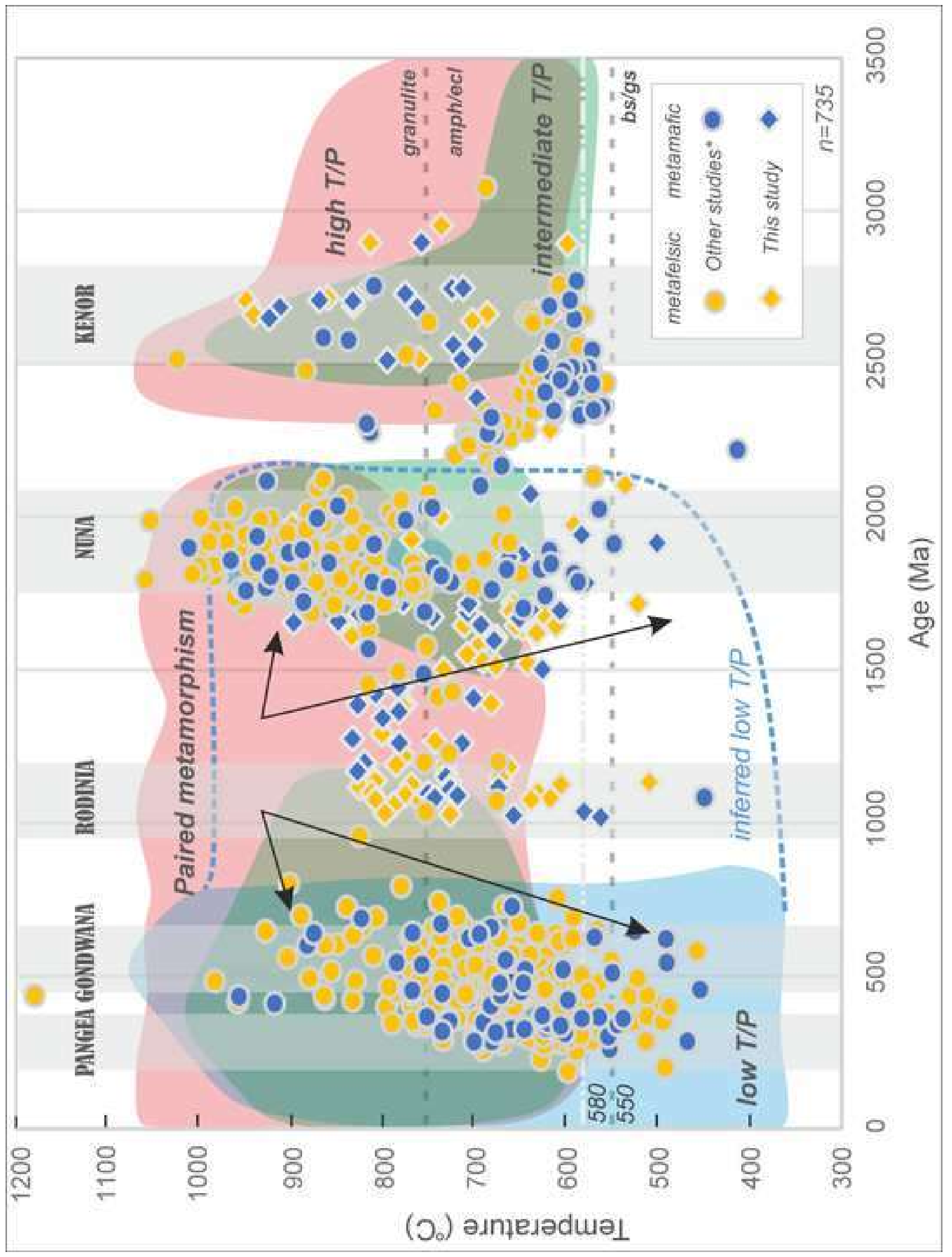


Click here to access/download Supplementary material for online publication only MMC1 - Met rutile Lit.xlsx 
Click here to access/download Supplementary material for online publication only MMC2 - trace and U-Pb detrital rutile.xIsx 
Click here to access/download Supplementary material for online publication only MMC3 - STD Rutile data.xIsx 
Click here to access/download Supplementary material for online publication only MMC4 - plate rutile.pdf 
Author's contributions: IP undertook sample collection and processing, SEM and LAICPMS work, data handling and interpretation, and has written the main parts of the manuscript. CS supervised the project and data processing, has discussed data interpretation, and substantively revised the manuscript. JD provided support during SEM and LA-ICPMS work. HM has been involved with data compilation, discussion and manuscript revision. RS and PAC have provided feedback and discussions related with the background research and have substantively revised the manuscript. All coauthors have contributed to the final version of this manuscript. 


\section{Declaration of interests}

$\bigotimes$ The authors declare that they have no known competing financial interests or personal relationships that could have appeared to influence the work reported in this paper.

$\square$ The authors declare the following financial interests/personal relationships which may be considered as potential competing interests: 